\title{
OPEN Modeling seasonal emergence of Poa annua in urban greenspace
}

\author{
Dallas R. Taylor ${ }^{1}$, Michael Prorock ${ }^{2}$, Brandon J. Horvath ${ }^{1}$ \& James T. Brosnan ${ }^{1 凶}$
}

Turfgrasses are perennial components of urban greenspaces found in parks, recreational areas, golf courses, sports fields, and lawns that confer many ecosystem services. A copious seed producer, Poa annua is the most troublesome weed of turfgrass and continually threatens the ecosystem services provided by urban greenspaces. Field research was conducted in Knoxville, TN to better understand environmental conditions triggering $P$. annua seedling emergence patterns to assist managers with optimally timing interventions-both chemical and non-chemical-for control. Fluctuations in cooling degree day $\left(\mathrm{CDD}_{21 c}\right)$ accumulation accounted for $82 \%$ of the variance in yearly cumulative $P$. annua emergence data collected in a single irrigated sward of hybrid bermudagrass [C. dactylon (L.) Pers. $x$. C. transvaalensis Burtt-Davy]. However, non-linear models using $C D_{21}$ data developed ex post were not able to accurately predict $P$. annua emergence patterns ex ante. In both years, $P$. annua emergence changed most rapidly between the 40th and $43 \mathrm{rd}$ week of the year when seven-day mean soil temperature and rainfall were $18.9^{\circ} \mathrm{C}$ and $12.7 \mathrm{~mm}$, respectively. Future research should explore the efficacy of herbicide mixtures applied when $P$. annua emergence is most rapidly changing in lieu of developing models to predict when specific emergence thresholds occur.

Urbanization of the world's population has increased focus on urban greenspaces and the ecosystem services they provide to people living in cities. Established sustainability goals set forth by the United Nations and the United States center upon mitigating increases in global temperature and protecting biodiversity to conserve ecosystem services ${ }^{1,2}$. Turfgrasses are perennial components of urban greenspaces found in parks, recreational areas, golf courses, sports fields, and lawns that confer a multitude of environmental and societal benefits from atmospheric enhancement to improved mental and physical well-being that have been reviewed in the literature ${ }^{3}$. Poa annua (annual bluegrass) is the most troublesome weed of managed turfgrass in urban greenspaces ${ }^{4}$. Having been documented on all continents including Antarctica ${ }^{5}$, P. annua is highly adaptable and noted for having ecotypes varying in morphological characteristics ${ }^{6}$. A day-neutral flowering plant ${ }^{7}, P$. annua seed germination has been studied in growth chamber environments with ecotypes germinating independent of daylight and across an air temperature range of 10 to $39^{\circ} \mathrm{C}^{8}$. At one location in Maryland, multiple $P$. annua seedling emergence events were noted in autumn, with peak emergence (50 to $70 \%$ ) occurring during a four-week period when air temperatures measured $\leq 20^{\circ} \mathrm{C}^{9}$. While information about air temperature effects on $P$. annua emergence is useful, a better understanding of factors such as soil temperature and soil moisture is warranted, particularly considering this species environmental adaptability. Additional information about edaphic factors triggering $P$. annua emergence could help managers combat widespread herbicide resistance in this species ${ }^{10}$ given that soil seedbank management is noted as a best management practice (BMP) for combatting resistance ${ }^{11}$.

Models have been developed using climatic data to aid managers in making pest management decisions in turfgrass systems. Heat accumulation, expressed as growing degree days (GDD), has been used to increase efficacy of plant growth regulator applications to both cool- and warm-season turfgrasses ${ }^{12-15}$ as well as to schedule preemergence herbicide applications for smooth crabgrass (Digitaria ischaemum Schreb.) control ${ }^{16}$. Recently, a model that tracked a five-day moving average of daily relative humidity and daily average air temperature was developed to aid turfgrass managers in making fungicide applications to control dollar spot (Clarireedia homoeocarpa $)^{17}$.

Ecosystem services provided by urban greenspaces are continually threatened by $P$. annua given that the species produces upwards of 100,000 seeds per square meter ${ }^{18-20}$. There is also widespread evidence that once established, $P$. annua can persist perennially ${ }^{6}$. There is a need to better understand environmental conditions triggering seedling emergence patterns to assist turfgrass managers with optimally timing interventions-both chemical and non-chemical-for P. annua control. The objective of this research was to model the emergence of P. annua in hybrid bermudagrass [C. dactylon (L.) Pers. x C. transvaalensis Burtt Davy]. 


\section{Materials and methods}

Our research involved the use of plant materials and all required permits and permissions required to conduct studies were obtained prior to trial initiation. All experiments were conducted in accordance with institutional, national, and international guidelines and legislation.

Yearly cumulative emergence. Field research was conducted at the East Tennessee AgResearch and Education Center- Plant Sciences Unit (ETREC; Knoxville, TN; $35.90^{\circ} \mathrm{N},-83.95^{\circ} \mathrm{W}$ ) from January 2019 through December 2020. The research site was located $255 \mathrm{~m}$ above sea level. Poa annua emergence was monitored in hybrid bermudagrass (cv. 'Tifway') maintained at $1.5 \mathrm{~cm}$ with a reel mower during periods of active growth; the site was not mowed during winter dormancy. This research site had a natural history of herbicide-susceptible $P$. annua infestation. Soil was a Sequatchie silt loam (fine-loamy, siliceous, semiactive, thermic humic Hapludult) with soil $\mathrm{pH} 6.2$ and water $\mathrm{pH}$ 6.1. Phosphorus (Mehlich-I), potassium, calcium, and magnesium concentrations in soil measured $11,73,970$, and $106 \mathrm{ppm}$, respectively.

Plots $(1 \mathrm{~m} \times 1 \mathrm{~m})$ were arranged in randomized complete block design (RCBD) with four replications. Within each replication, one plot was maintained as bare soil while the other was maintained as a hybrid bermudagrass. These two conditions were chosen to facilitate collection of emergence data over the widest span of turfgrass canopy cover. Bare-soil plots were maintained by physically removing aboveground hybrid bermudagrass biomass via scalping prior to the start of the experiment and periodically applying glyphosate at $1120 \mathrm{~g} \mathrm{ha}^{-1}$ (Roundup Pro. Bayer Environmental Sciences. St. Louis, MO) after collecting P. annua emergence data. Emergence was monitored inside a circle $\left(1000 \mathrm{~cm}^{2}\right)$ in the center of all eight plots. When an emerged $P$. annua seedling was present inside the circle, it was recorded, and then discarded with tweezers. Emerged weeds other than $P$. annua were removed using the same equipment and discarded. Each year P. annua emergence was assessed on a weekly basis from January 1 through May 31, biweekly from June 1 through August 31, and weekly from September 1 to December 31.

Environmental monitoring devices (Earthstream. Mesur.io. Yanceyville, NC) were installed in each plot to collect soil temperature ( $5 \mathrm{~cm}$ depth), air temperature, soil moisture (5 cm depth), and daily light integral data on 15-min intervals for the duration of the experiment. Meteorological data within a $20-\mathrm{m}$ radius of plots were also collected from publicly available sources including the National Oceanic \& Atmospheric Administration (NOAA), National Climate Reference Network, and the European Space Agency (ESA). Using data from auxiliary sources along with those captured by in-ground sensors reduced the risk of point sample information not accurately representing actual variable averages such that inferences could be made about $P$. annua across a wider scale than the immediate area around the in-ground sensor ${ }^{21}$.

Auxiliary locations. In order to expand inference beyond ETREC, data were collected at auxiliary locations during the autumn of 2020: Lambert Acres Golf Course (Alcoa, TN; $35.75^{\circ} \mathrm{N},-83.88^{\circ} \mathrm{W}$ ) and Three Ridges Golf Course (Knoxville, TN; $36.09^{\circ} \mathrm{N},-83.84^{\circ} \mathrm{W}$ ). At each auxiliary location, $P$. annua emergence was monitored in bermudagrass maintained at a $3.8 \mathrm{~cm}$ height of cut. Two plots $(1 \mathrm{~m} \times 1 \mathrm{~m})$ were placed at each location and separated $\geq 75 \mathrm{~m}$ from one another. Soil at Lambert Acres was an Emory silt loam (Fine-silty, siliceous, active, thermic Fluventic Humic Dystrudepts) with soil pH 5.4 and water pH 7.6. Phosphorus (Mehlich-I), potassium, calcium, and magnesium concentrations in soil measured 114, 250, 1595, and $148 \mathrm{ppm}$, respectively. Soil at Three Ridges was an Urban land-Udorthents complex with soil pH 5.9 and water pH 7.7. Phosphorus (MehlichI), potassium, calcium, and magnesium concentrations in soil measured 17, 278, 2150, and $230 \mathrm{ppm}$, respectively. Emergence of $P$. annua was monitored inside a circle $\left(1000 \mathrm{~cm}^{2}\right)$ in the center of each plot using methods previously described on a weekly basis from August 1 through November 30, 2020.

Model development. Emergence data were fit to non-linear functions using the Python (Python 3.8.7; python.org 2020) programming language. Emergence was modeled as a function of cooling degree day $\left(\mathrm{CDD}_{21 \mathrm{C}}\right)$ accumulation from the summer solstice given that Pearson's correlation analysis found it to be the strongest predictor of changes in P. annua emergence post-hoc in $2019(\mathrm{r}=0.90)$ of all 25 environmental parameters analyzed.

Several libraries were used in the model development process including 'pandas' for data handling (v. 1.2.0; https://pandas.pydata.org/), 'NumPy' for numerical operations (v. 1.19.0; https://numpy.org/), 'scikit learn' for model building (v. 0.24; https://scikit-learn.org/stable/), and 'SciPy' for curve fitting (v. 1.5.4; https://www.scipy. org/). Model visualization was conducted using both 'matplotlib' (v. 3.3.3; https://matplotlib.org/3.3.3/index. html) and 'seaborn' (v. 0.11.1; https://seaborn.pydata.org/).

Early season emergence. To better understand factors triggering P. annua emergence in autumn, early-season emergence ( 0 to $50 \%$ yearly total) and cooling degree day accumulation data were fit to the following Gompertz function [Eq. (1)] where,

$$
E S E=a * e^{-b * e^{-c * \mathrm{CDD} 21 \mathrm{C}}}
$$

ESE = early-season P. annua emergence (\%), $\mathrm{a}=$ the upper asymptote of the emergence curve, $\mathrm{b}=$ the displacement of the emergence curve along the $\mathrm{x}$-axis, $\mathrm{c}=$ the growth rate of the emergence curve, and $\mathrm{CDD}_{21 \mathrm{C}}=$ cooling degree days accumulated from the summer solstice using a $21^{\circ} \mathrm{C}$ base temperature. This model was developed ex post using data collected from ETREC in 2019 and validated at three locations in 2020: ETREC, Lambert Acres Golf Course, and Three Ridges Golf Course. 


\begin{tabular}{|l|l|l|l|l|}
\hline Year $^{\mathbf{a}}$ & Location & $\mathbf{R}^{\mathbf{2 b}}$ & MAE & MSLE \\
\hline 2019 & ETREC & 0.74 & 0.014 & 0.00081 \\
\hline 2020 & ETREC & 0.71 & 0.021 & 0.00118 \\
\hline & Three ridges & 0.26 & 0.037 & 0.00210 \\
\hline & Lambert acres & 0.31 & 0.026 & 0.00145 \\
\hline & All locations combined & 0.53 & 0.027 & 0.00154 \\
\hline
\end{tabular}

Table 1. Gompertz function to fit early season (0 to 50\% yearly maximum) P. annua emergence and cooling degree day accumulation data collected at the East Tennessee AgResearch and Education Center-Plant Sciences Unit (ETREC; Knoxville, TN) in 2019 and 2020, as well as Lambert Acres Golf Course (Alcoa, TN) and Three Ridges Golf Course (Knoxville, TN) in 2020. Emergence was monitored in plots ( $\left.1 \mathrm{~m}^{2}\right)$ established as a hybrid bermudagrass (C. dactylon L. Pers. x C. transvaalensis Burtt-Davy) on a weekly basis. ${ }^{\text {aErly season }}$ $P$. annua emergence data and cooling degree days $\left(\mathrm{CDD}_{21 \mathrm{C}}\right)$ accumulation data were fit to the following Gompertz function each year: Emergence $(\%)=0.485 \times \exp \left(-12.141 \times \exp \left(-0.081 \times \mathrm{CDD}_{21 \mathrm{C}}\right)\right)$. ${ }^{\mathrm{b}}$ Model fit was assessed using coefficient of determination $\left(\mathrm{R}^{2}\right)$, mean absolute error (MAE), and mean squared log error.

Yearly cumulative emergence. To better understand the entirety of $P$. annua emergence throughout autumn, yearly cumulative emergence data were regressed against $\mathrm{CDD}_{21 \mathrm{C}}$ accumulation and fit to a ruminal degradation curve [Eq. (2)] where,

$$
\mathrm{YCE}=-\mathrm{a}+\mathrm{b} *\left(1-e^{-\mathrm{c} * \mathrm{CDD} 21 \mathrm{C}}\right)
$$

YCE = yearly cumulative $P$. annua emergence $(\%), a+b=$ the $y$-axis offset of the emergence curve, $c=$ the growth rate of the emergence curve, and $\mathrm{CDD}_{21 \mathrm{C}}=$ cooling degree days accumulated from the summer solstice using a $21{ }^{\circ} \mathrm{C}$ base temperature. This model was developed using data collected from ETREC in 2019 and validated using data collected there in 2020.

Model fit. In all cases, model fit was determined using three parameters: coefficient of determination $\left(\mathrm{R}^{2}\right)$, mean absolute error (MAE), and mean squared log error (MSLE). MAE provided an assessment of error between paired observations expressing the same phenomenon ${ }^{22}$, while MSLE measured the average of the squares of these errors ${ }^{23}$. All statistical analyses are available in a Google collaborative environment at: https://colab.resea rch.google.com/drive/1-FRzYuPFtLk-2u_26vzFcmW9_Zc_sEvi?usp=sharing.

\section{Results}

Early season emergence. A Gompertz function fit early-season $P$. annua emergence data collected at ETREC well in 2019 (Table 1, Fig. 1). However, MAE and MSLE values for this model increased in 2020 at ETREC and the auxiliary locations. Moreover, $\mathrm{R}^{2}$ values were markedly lower in 2020 compared to 2019. For example, using data collected at ETREC, the $\mathrm{R}^{2}$ value for this model measured 0.74 in 2019 compared to 0.71 in 2020; values for the auxiliary locations in 2020 were $\leq 0.31$ suggesting that this model fit emergence data at these sites worse than ETREC.

At ETREC in 2019, P. annua emergence was documented when $12 \mathrm{CDD}_{21 \mathrm{C}}$ accumulated (September 4 ). In 2020, initial emergence was documented at ETREC when $8 \mathrm{CDD}_{21 \mathrm{C}}$ accumulated (August 5), almost a full month earlier than 2019. Earlier P. апnua emergence could be related to cooler air temperature as monthly averages were lower in 2020 for both August $\left(24.9^{\circ} \mathrm{C}\right.$ versus $\left.25.8^{\circ} \mathrm{C}\right)$ and September $\left(21.2^{\circ} \mathrm{C}\right.$ versus $\left.25.8^{\circ} \mathrm{C}\right)$. Air temperatures where $P$. annua emergence was initially observed each year were within the 10 to $39^{\circ} \mathrm{C}$ range previously reported in a growth chamber ${ }^{8}$. However, it should be noted that air temperature might not be the best predictor given that emergence was not documented at either auxiliary location in 2020 until $72 \mathrm{CDD}_{21 \mathrm{C}}$ accumulated on October 1 (Fig. 1). This discrepancy in emergence timing between ETREC and the auxiliary locations may be related to soil moisture considering that plots at the auxiliary locations were irrigated only via rainfall whereas those at ETREC received both rainfall and supplemental irrigation. In a field study of cover crops, solarization, and fumigation on management weed seedbanks, $P$. annua emerged following rainfall events in late summer or early fall ${ }^{24}$. In our experiment with turfgrass, $P$. annua emergence occurred two days after auxiliary locations received 78.6 to $87.7 \mathrm{~mm}$ rainfall in a six-day period.

Yearly cumulative emergence. A ruminal degradation curve fit yearly cumulative $P$. annua emergence data collected at ETREC well in 2019 (Table 2, Fig. 2). However, MAE and MSLE values for this model increased in 2020 and the coefficient of determination decreased (Table 2). Despite the increases in overall MAE and MSLE values, findings illustrate that $\mathrm{CDD}_{21 \mathrm{C}}$ accumulation accounted for over $82 \%$ of the variation in $P$. annua emergence at the ETREC location over a 2-year period.

In 2019, P. annua emergence was first documented at ETREC when $12 \mathrm{CDD}_{21 \mathrm{C}}$ accumulated and continued throughout autumn. Emergence measured $50 \%$ by the time $141 \mathrm{CDD}_{21 \mathrm{C}}$ had accumulated (October 27), and reached $75 \%$ by the time $288 \mathrm{CDD}_{21 \mathrm{C}}$ accumulated (November 9 ). Using 2019 total plant count data, peak emergence ( $61 \%$ of the yearly total) occurred during the 4 -week period between October 11 and November 3, which corresponded to 32 to $211 \mathrm{CDD}_{21 \mathrm{C}}$. Average day/night air temperatures during this period were $20.3 / 8.2{ }^{\circ} \mathrm{C}$, 


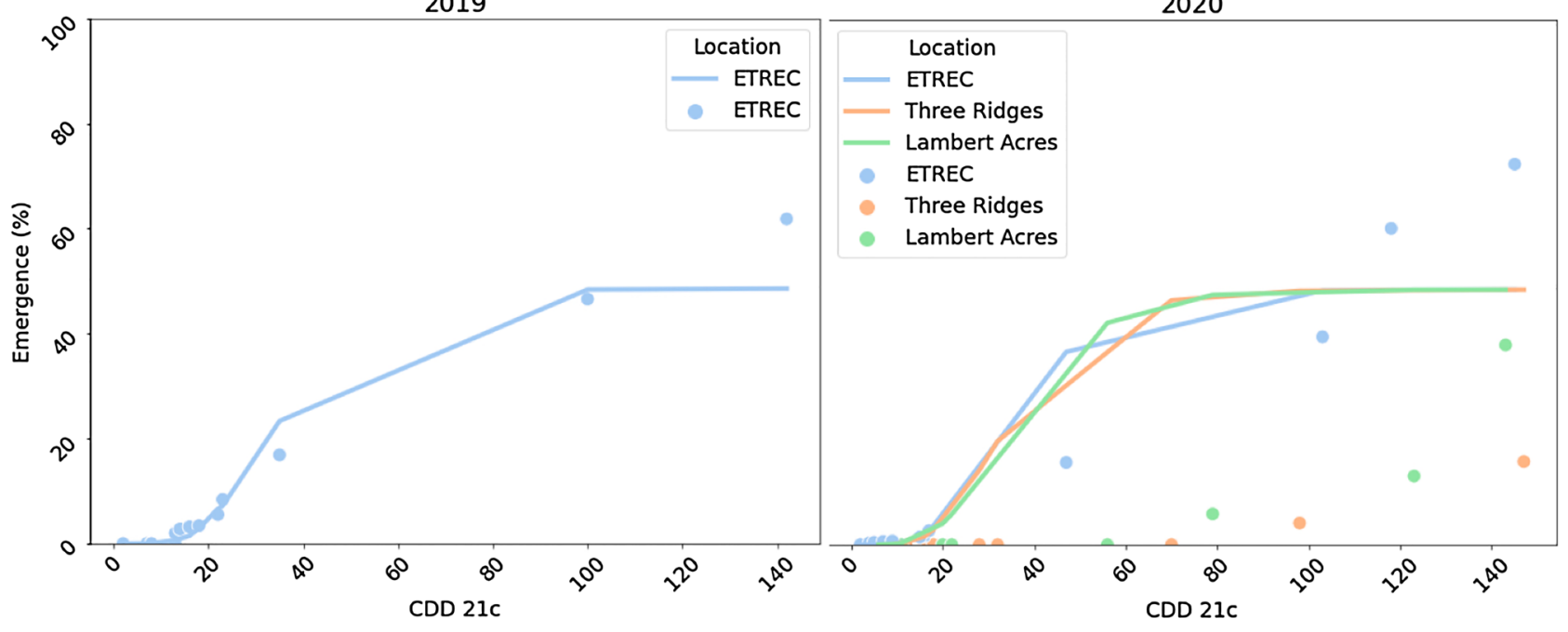

Figure 1. Gompertz function fit to early season (0 to 50\% yearly maximum) P. annua emergence data collected at the East Tennessee AgResearch \& Education Center-Plant Sciences Unit (Knoxville, TN) in 2019 and 2020, as well as Lambert Acres Golf Course (Alcoa, TN) and Three Ridges Golf Course (Knoxville, TN) in 2020.

Emergence data were collected weekly with observations were regressed over cooling degree days $\left(\mathrm{CDD}_{21 \mathrm{C}}\right)$ with accumulation beginning at the summer solstice using a $21^{\circ} \mathrm{C}$ base temperature. Colored circles represent actual observations whereas the solid line represents model predictions. Measures of model fit for each location and year are presented in Table 1.
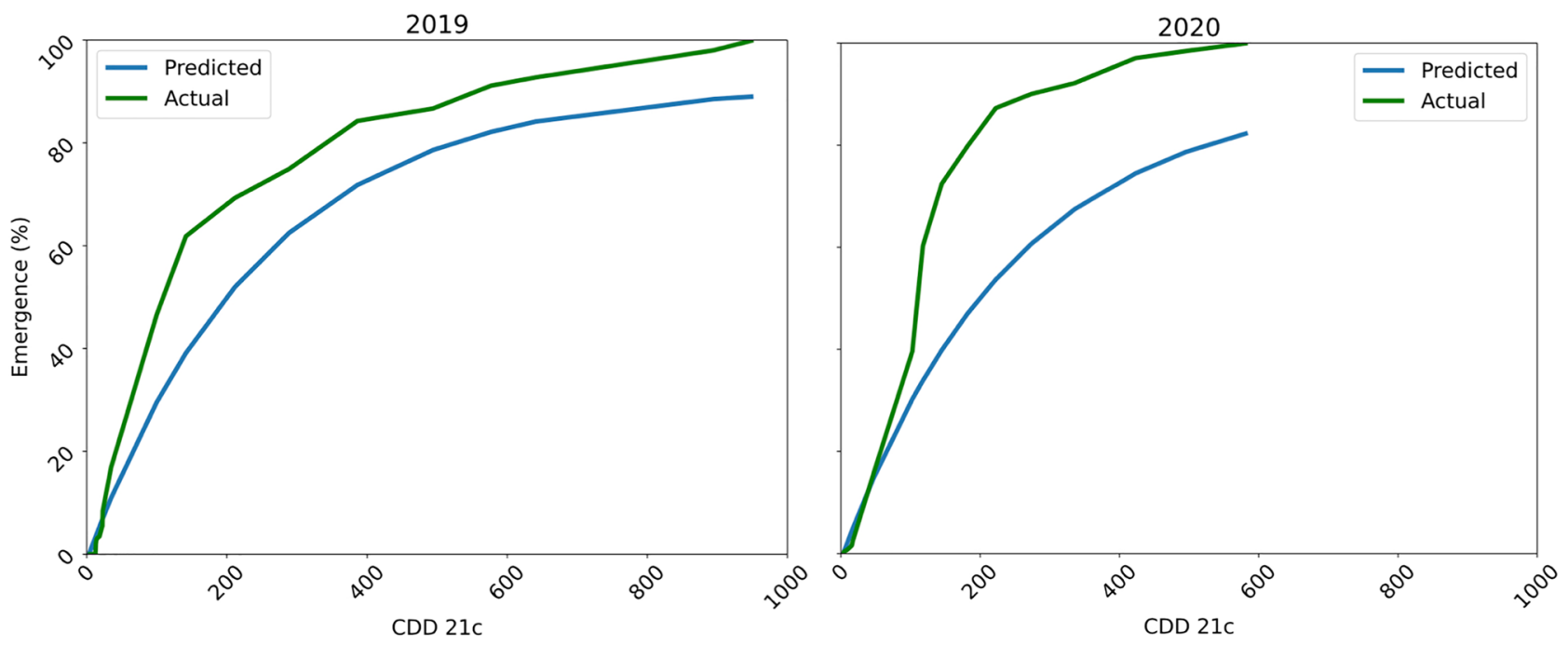

Figure 2. Four-parameter ruminal degradation curve to fit yearly cumulative $P$. annua emergence data collected at East Tennessee AgResearch and Education Center-Plant Sciences Unit (Knoxville, TN) in 2019 and 2020. Emergence was monitored on a weekly basis in plots $\left(1 \mathrm{~m}^{2}\right)$ established as a hybrid bermudagrass $(C$. dactylon L. Pers. x C. transvaalensis Burtt-Davy, cv. 'Tifway') fairway and maintained as bare soil. Combined observations were regressed over cooling degree day accumulation from the summer solstice using a $21^{\circ} \mathrm{C}$ base temperature $\left(\mathrm{CDD}_{21 \mathrm{C}}\right)$. The blue line represents model predictions whereas the green line represents actual observations each year. Measures of model fit for each year are presented in Table 2. 


\begin{tabular}{|l|l|l|l|}
\hline Year $^{\mathbf{a}}$ & $\mathbf{R}^{\mathbf{2 b}}$ & MAE & MSLE \\
\hline 2019 & 0.95 & 0.062 & 0.0031 \\
\hline 2020 & 0.82 & 0.119 & 0.0111 \\
\hline
\end{tabular}

Table 2. Ruminal degradation curve fit to full season $P$. annua emergence and cooling degree day accumulation data collected at East Tennessee AgResearch and Education Center-Plant Sciences Unit (ETREC) (Knoxville, TN) in 2019 and 2020. Emergence was monitored on a weekly basis in plots $\left(1 \mathrm{~m}^{2}\right)$ established as a hybrid bermudagrass (C. dactylon L. Pers. x C. transvaalensis Burtt-Davy, cv. 'Tifway') fairway and maintained as bare soil. ${ }^{a}$ Yearly cumulative $P$. annua emergence data and cooling degree days $\left(\mathrm{CDD}_{21 \mathrm{C}}\right)$ accumulation data were fit to the following ruminal degradation function: Emergence $(\%)=$ $-0.01275+0.9220+\left(1-\exp \left(-0.004 \times \mathrm{CDD}_{21 \mathrm{C}}\right)\right)$. ${ }^{\mathrm{b}}$ Model fit was assessed using coefficient of determination $\left(\mathrm{R}^{2}\right)$, mean absolute error (MAE), and mean squared log error.

respectively, whereas soil temperature averaged $16.6^{\circ} \mathrm{C}$. These observations in 2019 align with the findings of Kaminski and Dernoeden ${ }^{9}$ who recorded P. annua emergence in cool-season turfgrass once air temperatures fell to $20^{\circ} \mathrm{C}$. Additionally, McElroy et al. ${ }^{8}$ reported that the optimal air temperature for $P$. annua germination in a growth chamber occurred at $19^{\circ} \mathrm{C}$.

In 2020, P. annua emergence was first documented at ETREC after $8 \mathrm{CDD}_{21 \mathrm{C}}$ accumulated on August 5th and continued throughout autumn. Emergence in 2020 reached $50 \%$ and $75 \%$ by the time $117 \mathrm{CDD}_{21 \mathrm{C}}\left(\mathrm{O}_{\text {ctober }}\right.$ 9) and $188 \mathrm{CDD}_{21 \mathrm{C}}$ accumulated (October 22nd), respectively. Peak P. annua emergence (61\% of yearly total) occurred during the four-week period between September 24 and October 16, which corresponded to 46 to 145 $\mathrm{CDD}_{21 \mathrm{C}}$. Average day/night air temperatures during this period were $22.7 / 11.2{ }^{\circ} \mathrm{C}$, respectively, whereas soil temperatures averaged $18.9^{\circ} \mathrm{C}$. This period of peak emergence at ETREC occurred earlier in 2020 than 2019 and air temperature alone does not explain this difference considering that day/night air temperature averages during this four-week period were higher in 2020 than 2019. Interestingly, there were substantial differences in rainfall between years that may explain the shift in the period of peak emergence. In 2019, rainfall totaled $139.7 \mathrm{~mm}$ for the months September and October, respectively, compared to $226.6 \mathrm{~mm}$ in 2020.

The yearly cumulative emergence model developed using 2019 data collected at ETREC underpredicted emergence in 2020 (Fig. 2). For example, this model suggested that $50 \%$ and $75 \%$ annual bluegrass emergence would occur at 225 and $445 \mathrm{CDD}_{21 \mathrm{C}}$, respectively. In 2020, these benchmark targets were met at 117 and 181 $\mathrm{CDD}_{21 \mathrm{C}}$, respectively. Increased soil moisture may have influenced P. annua emergence in 2020. Although ETREC received irrigation to supplement rainfall, there was an $87 \mathrm{~mm}$ difference in rainfall accumulation during September through October 2020 compared to 2019 . Further, $\mathrm{CDD}_{21 \mathrm{C}}$ only accounted for $82 \%$ of the variability in emergence data collected in 2020 compared to 95\% in 2019 (Table 2). This difference in rainfall over years may explain this change and suggests that future models incorporate both parameters.

\section{Discussion}

While non-linear models were able to fit both early-season and yearly cumulative $P$. annua emergence data $e x$ post in 2019, they were not able to accurately predict the same phenomenon in 2020. Future research could be conducted using the 24-month dataset generated in this study to develop new models to predict $P$. annua emergence benchmarks. However, a model with applicability over a wide geographic range would require a vast amount of data for validation. Is such a research effort worthwhile given the environmental adaptability of $P$. annua and the array of edaphic factors that can affect weed seed emergence from soil?

Mixtures of pre- and postemergence herbicides are recommended for controlling weeds like P. annua known to evolve resistance to herbicides ${ }^{25,26}$. Managers are charged with applying pre- and postemergence mixtures when emergence is most rapidly changing. Cumulative $P$. annua emergence at all locations in this 24 -month study is presented in Fig. 3. Emergence changed most rapidly between the 40th and 43rd week of the year. Interestingly edaphic factors during this window were consistent in both 2019 and 2020. Seven-day mean soil temperature $(5 \mathrm{~cm})$ was $18.9^{\circ} \mathrm{C}\left( \pm 0.39^{\circ} \mathrm{C}\right)$ and seven-day mean rainfall was $12.7 \mathrm{~mm}( \pm 0.6 \mathrm{~mm})$. Future research exploring efficacy of pre- and postemergence herbicide mixtures applied for P. annua control using these benchmarks is warranted. Turfgrass managers often implement measures to control fungal pathogens such as Rhizoctonia solani AG2-2 LP and Ophiospherella spp. using similar edaphic benchmarks ${ }^{27,28}$ and may readily implement measures for P. annua control at this timing as well.

Overall, fluctuations in $\mathrm{CDD}_{21 \mathrm{C}}$ accounted for $\geq 82 \%$ of the variance in yearly cumulative $P$. annua emergence data collected in an irrigated hybrid bermudagrass fairway at ETREC. However, non-linear models developed ex post were not able to accurately predict $P$. annua emergence patterns ex ante. Given edaphic conditions facilitating the most rapid changes in $P$. annua emergence were similar over years, future research should explore efficacy of herbicide mixtures applied at this timing in lieu of developing models to predict when thresholds of $P$. annua emergence (e.g., $25 \%, 50 \%$, etc.) occur. 


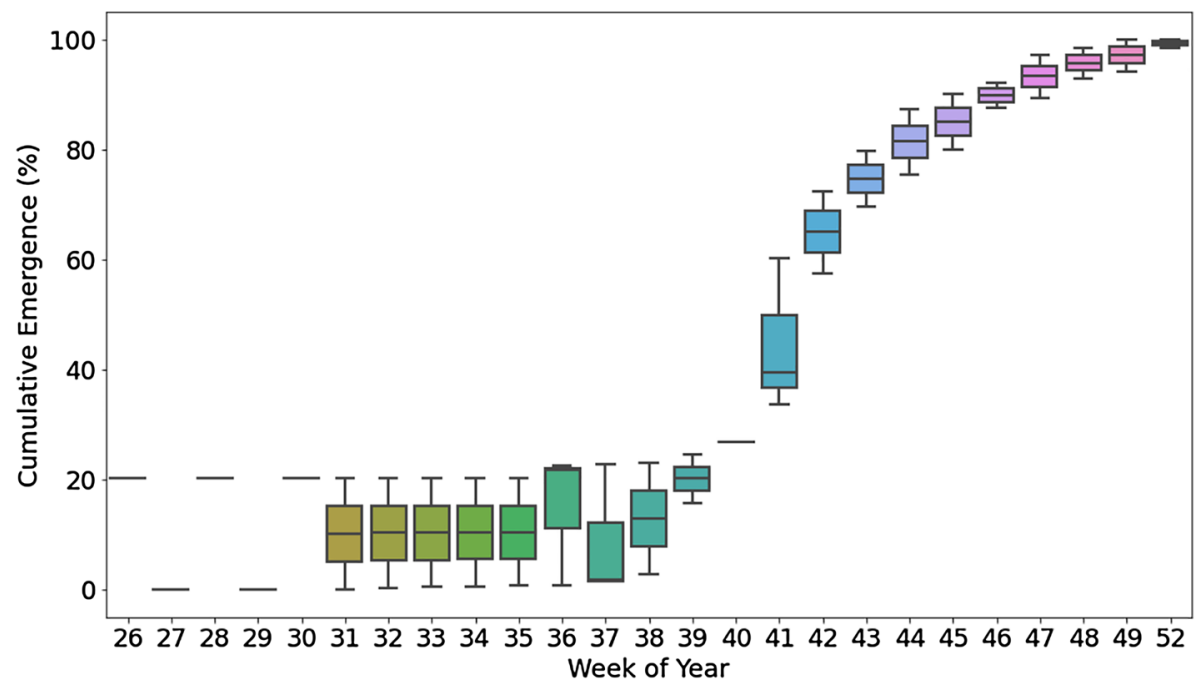

Figure 3. Weekly changes in P. annua emergence during 2019 and 2020 at three locations in East Tennessee: East Tennessee AgResearch \& Education Center-Plant Sciences Unit (Knoxville, TN; $35.90^{\circ} \mathrm{N},-83.95^{\circ} \mathrm{W}$ ), Lambert Acres Golf Course (Alcoa, TN; $35.75^{\circ} \mathrm{N},-83.88^{\circ} \mathrm{W}$ ), Three Ridges Golf Course (Knoxville, TN; $36.09^{\circ} \mathrm{N},-83.84^{\circ} \mathrm{W}$ ). Boxes represent 25,50 , and $75 \%$ percentiles with minimum and maximum values represented by vertical bars.

Received: 25 June 2021; Accepted: 9 September 2021

Published online: 23 September 2021

\section{References}

1. United Nations Economic and Social Council. Special edition: progress towards the sustainable development goals report of the secretary-general. Advanced Unedited Version. https://sustainabledevelopment.un.org/content/documents/22700E_2019_XXXX_ Report_of_the_SG_on_the_progress_towards_the_SDGs_Special_Edition.pdf. (2021).

2. The White House. Executive order on tackling the climate crisis at home and abroad. https://www.whitehouse.gov/briefing-room/ presidential-actions/2021/01/27/executive-order-on-tackling-the-climate-crisis-at-home-and-abroad/. (2021).

3. Brosnan, J. T. et al. A justification for continued management of turfgrass during economic contraction. Agric. Environ. Lett. 5, 1-8. https://doi.org/10.1002/ael2.20033 (2020).

4. Van Wychen, L. Survey of the most common and troublesome weeds in grass crops, pasture and turf in the United States and Canada. Weed Science Society of America National Weed Survey Dataset. https://wssa.net/wssa/weed/surveys/ (2021).

5. Olech, M. Human impact on terrestrial ecosystems in west Antarctica. Polar Biol. 9, 299-306 (1996).

6. Carroll, D. E. et al. Current understanding of the Poa annua life cycle. Crop Sci. 61, 1527-1537. https://doi.org/10.1002/csc2.20441 (2020).

7. Johnson, P. G. \& White, D. B. Flowering responses of selected annual bluegrass genotypes under different photoperiod and cold treatments. Crop Sci. 37, 1543-1547 (1997).

8. McElroy, J. S., Walker, R. H., Wehtje, G. R. \& van Santen, E. Annual bluegrass (Poa annua) populations exhibit variation in germination response to temperature, photoperiod, and fenarimol. Weed Sci. 52, 47-52 (2004).

9. Kaminski, J. E. \& Dernoeden, P. H. Seasonal Poa annua L. seedling emergence patterns in Maryland. Crop Sci. 47, 775-779 (2007).

10. Heap, I. International survey of herbicide resistant weeds. http://www.weedscience.org. (2021).

11. Norsworthy, J. K. et al. Reducing the risks of herbicide resistance: Best management practices and recommendations. Weed Sci. 60(SP1), 31-62 (2012).

12. Danneberger, T. K., Branham, B. E. \& Vargas, J. M. Mefluidide applications for annual bluegrass seedhead suppression based on degree-day accumulation. Agron. J. 79, 69-71 (1987).

13. Danneberger, T. K. \& Vargas, J. M. Annual bluegrass seedhead emergence as predicted by degree-day accumulation. Agron. J. 76, 756-758 (1984).

14. Kreuser, W. C. \& Soldat, D. J. A growing degree day model to schedule trinexapac-ethyl applications on Agrostis stolonifera golf putting greens. Crop Sci. 51, 2228-2236 (2011).

15. Reasor, E. H. et al. Growing degree day models for plant growth regulator applications on ultradwarf hybrid bermudagrass putting greens. Crop Sci. 58, 1801-1807 (2018).

16. Fidanza, M. A., Dernoeden, P. H. \& Zhang, M. Degree-days for predicting smooth crabgrass emergence in cool-season turfgrasses. Crop Sci. 36, 990-996 (1996).

17. Smith, D. L. et al. Development and validation of a weather-based warning system to advise fungicide applications to control dollar spot on turfgrass. PLoS ONE https://doi.org/10.1371/journal.pone.0194216 (2018).

18. Gaussoin, R. E. \& Branham, B. E. Influence of cultural factors on species dominance in a mixed stand of annual bluegrass/creeping bentgrass. Crop Sci. 29, 480-484 (1989).

19. Lush, W. M. Biology of Poa annua in a temperate zone golf putting green (Agrostis stolonifera/Poa annua) II. The Seed Bank. J. Appl. Ecol. 25, 989-997 (1988).

20. Watschke, T. L., Long, F. W. \& Duich, J. M. Control of Poa annua by suppression of seedheads with growth regulators. Weed Sci. 27, 224-231 (1979).

21. Kirk-Davidoff, D. B., Goody, R. M. \& Anderson, J. G. Analysis of sampling errors for climate monitoring satellites. J. Clim. 18, $810-822(2005)$.

22. Mean Absolute Error. in: Sammut C., Webb G. I. (eds) Encyclopedia of Machine Learning. (Springer, 2021). https://doi.org/10.1007/ 978-0-387-30164-8 525. 
23. Mean Squared Error. in: Sammut C., Webb G. I. (eds) Encyclopedia of Machine Learning. (Springer, 2021). https://doi.org/10.1007/ 978-0-387-30164-8_528.

24. Peachey, P. E., Pinkerton, J. N., Ivors, K. L., Miller, M. L. \& Moore, L. W. Effect of soil solarization, cover crops, and metham on field emergence and survival of buried annual bluegrass (Poa annua) seeds. Weed Technol. 15, 81-88 (2001).

25. Busi, R., Powles, S. B., Beckie, H. J. \& Renton, M. Rotations and mixtures of soil-applied herbicides delay resistance. Pest Manag. Sci. 76, 487-496 (2020).

26. Breeden, S. et al. Confirmation and control of annual bluegrass (Роа annua) with resistance to prodiamine and glyphosate. Weed Technol. 31, 111-119 (2017)

27. Green, D. E. II., Fry, J. D., Pair, J. C. \& Tisserat, N. A. Pathogenicity of Rhizoctonia solani AG-2-2 and Ophiosphaerella herpotricha on zoysiagrass. Plant Dis. 77, 1040-1044 (1993).

28. Tredway, L. P., Tomaso-Peterson, M., Perry, H. \& Walker, N. R. Spring dead spot of bermudagrass: A challenge for researchers and turfgrass managers. Plant Health Progress. https://doi.org/10.1094/PHP-2009-0710-01-RV (2009).

\section{Acknowledgements}

Authors would like to acknowledge Tom Mueller, Larry Steckel, Greg Breeden, Javier Vargas, Devon Carroll, and Ben Pritchard for their support of this research. Additionally, authors would like to thank the Tennessee Chapter of the Golf Course Superintendents Association of America, the Tennessee Turfgrass Association, as well as the University of Tennessee Institute of Agriculture.

\section{Author contributions}

D.R.T. responsible for data curation, investigation, and writing original draft. M.P. responsible for data curation, formal analysis, software, validation, visualization. B.J.H. responsible for methodology, validation, as well as review and editing of draft. J.T.B. responsible for conceptualization, funding acquisition, methodology, project administration, resources, supervision, visualization, as well as review and editing of draft.

\section{Competing interests}

The authors declare no competing interests.

Additional information

Correspondence and requests for materials should be addressed to J.T.B.

Reprints and permissions information is available at www.nature.com/reprints.

Publisher's note Springer Nature remains neutral with regard to jurisdictional claims in published maps and institutional affiliations.

(c) (i) Open Access This article is licensed under a Creative Commons Attribution 4.0 International License, which permits use, sharing, adaptation, distribution and reproduction in any medium or format, as long as you give appropriate credit to the original author(s) and the source, provide a link to the Creative Commons licence, and indicate if changes were made. The images or other third party material in this article are included in the article's Creative Commons licence, unless indicated otherwise in a credit line to the material. If material is not included in the article's Creative Commons licence and your intended use is not permitted by statutory regulation or exceeds the permitted use, you will need to obtain permission directly from the copyright holder. To view a copy of this licence, visit http://creativecommons.org/licenses/by/4.0/.

(c) The Author(s) 2021 